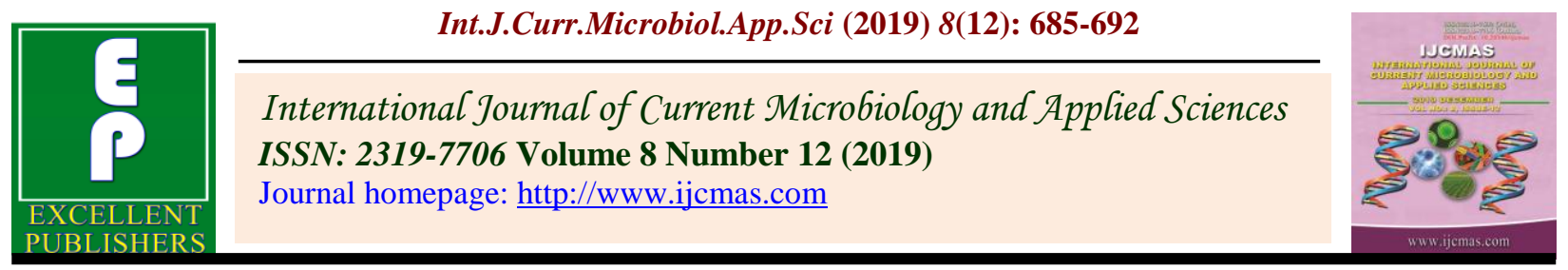

Original Research Article

https://doi.org/10.20546/ijcmas.2019.812.090

\title{
Effect of Nutrient Management in Growth, Development and Productivity of Late Transplanted Rice (Oryza sativa L.)
}

\author{
Sudeshnamayee Sahoo, Koushik Sar*, A.K. Mohapatra and J.M L. Gulati \\ Department of Agronomy, Faculty of Agricultural Sciences (IAS), Siksha 'O' Anusandhan \\ (Deemed to be University), Bhubaneswar-751029, Odisha, India \\ *Corresponding author
}

\begin{tabular}{|l|}
\hline Key w o r d s \\
Growth, Cereal \\
food crop, \\
Plateauing, Yield \\
barrier, Dry matter \\
production
\end{tabular}

A B S T R A C T
A field experiment entitled "Effect of Nutrient management in growth, development and productivity of late transplanted rice (Oryza sativa L.)" was conducted at the SOA University, Institute of Agricultural Science, Campus-4, Bhubaneswar during kharif season to assess the growth, yield attributes and yield as influenced by fertilizer management practices of two rice varieties. The experiment was laid out in a factorial design with two varieties (Naveen and Pratiskhya) and five nutrient combinations (F1: 80: $40: 40 \mathrm{~N}: \mathrm{P}: \mathrm{K} \mathrm{Kg} \mathrm{ha}^{-1}$ (100\% RDF), F2: 100 : 50: $50 \mathrm{~N}: \mathrm{P}: \mathrm{K} \mathrm{Kg} \mathrm{ha}^{-1}$ (125\% RDF), F3: F1 + $25 \mathrm{Kg}$ $\mathrm{ZnSO}_{4} \mathrm{ha}^{-1}$, F4: F1+ $10 \mathrm{Kg}_{\text {Borax ha }}{ }^{-1}, \mathrm{~F} 5: \mathrm{F} 1+25 \mathrm{Kg} \mathrm{ZnSO}_{4} \mathrm{ha}^{-1}$. $+10 \mathrm{Kg}$ Borax $\mathrm{ha}^{-1}$ ) and replicated thrice. Plants of rice variety Pratiskhya grew rapidly at all the stages of growth having more number of tillers and accumulated more dry matter than the ruling cultivar Naveen. It also produced more number of panicles, containing more bold grains with fewer chaffs as compared to Naveen. Interactive effect of Pratiskhya along with NPK (RDF) $+\mathrm{S}+\mathrm{Zn}+\mathrm{B}$ produced the highest grain yield as compared to Naveen and NPK (RDF) $+\mathrm{S}+$ $\mathrm{Zn}+\mathrm{B}$.

\section{Introduction}

The most important cereal food crop of the world is Rice. Rice is grown in 114 countries across the world on an area about 150 million hectares (nearly $11 \%$ of the world's cultivated land) with an annual production of over 525 million tons (Rai, 2006). Yet by 2025, a $40 \%$ increase in global demand for rice is anticipated in response to increasing population.

In Odisha rice is cultivated in 4.18 million ha with a production of 7.58 million tonnes and average yield of $1815 \mathrm{~kg} \mathrm{ha}^{-1}$. The reasons for low productivity of rice in the state are many. Use of traditional varieties, time of planting, imbalanced fertilizer use and low fertilizer use 
efficiency are the main reasons in achieving higher productivity in the coastal alluvial soils of Odisha.

While analyzing the causes of yield plateauing in irrigated ecosystems, Freeman et al., (1993) believed that manipulation of the physiological frame of the present day varieties would be one of the means for breaking the yield barrier. Khush (1993), however, emphasized the importance of total dry matter production, partitioning of dry matter between grains and other plant parts, large and active sink and harvest index in order to cause significant advances in yield. But to achieve time bound production goals, the physiological manipulation approach would deliver no immediate good. Thus, to meet the production targets in a short span of time, among varieties of innovative approaches, exploitation considered to be the most prospective one to raise genetic ceiling for rice yield levels in high productive areas. As cropping intensity and yield levels go up, so is the mining of plant nutrients through harvested crops. This had has caused the deficiency of micronutrients in the state, which are indispensable for normal plant growth and development. Its deficiency is one of the major problems in achieving targeted yield of rice. Different rice varieties respond differently to levels of fertility under different climatic conditions. So to realize the inherited yield potential from under a particular set of environmental condition, it is essential to investigate and spell out ideal variety(s) and optimum fertilizer dose for the concerned variety.

\section{Materials and Methods}

The present investigation was carried out in in the SOA University, Institute of Agricultural Science, Campus-4, Bhubaneswar during kharif seasons 2018 with 2 different varieties and 5 Nutrient management practices viz- $\mathrm{F}_{1}$ :
80: 40 : $40 \mathrm{~N}: \mathrm{P}: \mathrm{K} \mathrm{Kg} \mathrm{ha}^{-1}(100 \% \mathrm{RDF}), \mathrm{F}_{2}$ : 100 : 50: $50 \mathrm{~N}: \mathrm{P}: \mathrm{K} \mathrm{Kg} \mathrm{ha}^{-1}$ (125\% RDF), $\mathrm{F}_{3}$ : $\mathrm{F}_{1}+25 \mathrm{Kg} \mathrm{ZnSO}_{4} \mathrm{ha}^{-1}, \mathrm{~F}_{4}: \mathrm{F}_{1}+10 \mathrm{Kg}$ Borax $\mathrm{ha}^{-1}, \mathrm{~F}_{5}: \mathrm{F}_{1}+25 \mathrm{Kg} \mathrm{ZnSO}_{4} \mathrm{ha}^{-1}+10 \mathrm{Kg}$ Borax ha- ${ }^{-1}$. The experiment was laid out in Factorial RBD, replicated thrice. After harvest of crop, N, P, K, S, Zn and B contents of grain and straw were determined taking composite samples using the standard procedures and expressed as percentage.

\section{Results and Discussion}

\section{Growth studies}

\section{Plant height}

The height increased progressively after planting and reached its maximum at harvest (Table 3). Pratiskhya variety, application of 80: 40: $40 \mathrm{~N}: \mathrm{P}: \mathrm{K} \mathrm{kg} /$ ha. $+25 \mathrm{~kg} \mathrm{ZnSO} /$ ha. $+10 \mathrm{~kg}$ Borax/ ha produced taller plants over other treatment combinations. Plants of rice variety Pratiskhya had significantly taller plants than the variety Naveen at all stages of growth. Pratiskhya variety recorded an average height of $51.2 \mathrm{~cm}$ at 20 DAT and that increased progressively to $93.6 \mathrm{~cm}$ at $60 \mathrm{DAT}$ and $95.8 \mathrm{~cm}$ at harvest. Check variety Naveen could record a height of only $91 \mathrm{~cm}$ at harvest. Significant increase in plant height of Pratiskhya could be attributed to more vigorous growth at successive stages of growth and better response to nutrients applied, available solar radiation and prevailing microclimatic conditions. Mahajan et al., (2010) opined that variation in plant height could be due to their genetic makeup and its adaptation to environment.

Nutrient management practices influenced the plant height significantly at all growth stages and at harvest. Maximum plant height of $59.5 \mathrm{~cm}$ was obtained with the application of 80: 40: $40 \mathrm{~N}: \mathrm{P}: \mathrm{K} \mathrm{kg} / \mathrm{ha} .+25 \mathrm{~kg} \mathrm{ZnSO}$ /ha. + $10 \mathrm{~kg}$ Borax/ ha at $20 \mathrm{DAT}$ which increased to 
$103 \mathrm{~cm}$ at 60 DAT and was maximum $105 \mathrm{~cm}$ at harvest followed by that of NPK $+25 \mathrm{~kg}$ $\mathrm{ZnSO}_{4} / \mathrm{ha}(101.5 \mathrm{~cm})$ and both were at par. Application of $100 \%$ RDF recorded the minimum plant height. These results are in agreement with the findings of Mohapatra (2004) who got maximum plant height in Lalat with application of NPK $+\mathrm{S}+\mathrm{Zn}$ and B.

\section{Number of tillers per hill}

The number of tillers per hill increased progressively up to 60 DAT and then decreased. Pratiskhya variety, application of 80: 40: $40 \mathrm{~N}: \mathrm{P}: \mathrm{K} \mathrm{kg} / \mathrm{ha} .+25 \mathrm{~kg} \mathrm{ZnSO} / \mathrm{ha}$. + $10 \mathrm{~kg}$ Borax/ ha produced maximum number of tillers.

In all growth stages, rice Pratiskhya variety had significantly more number of tillers per hill followed by variety Naveen. The mean number of tillers per hill at 20,40 and 60 DAT in Naveen variety were 6.44, 12.76 and 13.6, respectively and in Pratiskhya, the mean number of tillers per hill at 20, 40 and 60 DAT were 8.06, 13.52 and 14.22. Rao et al.,(2014) got more numbers of tillers in Rice variety BPT5204 which was ascribed to its genetic makeup and prevalence of optimum weather condition which contributed to longer vegetative growth and higher GDD(heat unit requirement).

Nutrient management practices influenced the number of tillers per hill significantly at all growth stages and at harvest. Maximum number of tillers per hill with the application of $80: 40: 40 \quad \mathrm{~N}: \quad \mathrm{P}: \quad \mathrm{K} \quad \mathrm{kg} / \mathrm{ha}+25 \mathrm{~kg}$ $\mathrm{ZnSO}_{4} / \mathrm{ha}+10 \mathrm{~kg}$ Borax/ha was recorded at all growth stages which was followed by $\mathrm{F}_{1}+25 \mathrm{kgZnSO}_{4} /$ ha which was at par with the treatment $\mathrm{F}_{2}(100: 50: 50 \mathrm{~N}: \mathrm{P}: \mathrm{K} \mathrm{kg} / \mathrm{ha}, 125 \%$ RDF). The application of $F_{1}(80: 40: 40 \mathrm{~N}: \mathrm{P}$ : $\mathrm{K} \mathrm{kg} / \mathrm{ha} 100 \% \mathrm{RDF}$ ) recorded the minimum number of tillers per hill at all stages of crop growth. The mean number of tillers per hill at
20, 40 and 60 DAT in treatment $F_{1}+25 \mathrm{~kg}$ $\mathrm{ZnSO}_{4} / \mathrm{ha}+10 \mathrm{~kg}$ Borax/ha were 8.95 , 15. 5 and 16.2 and those with $\mathrm{F}_{1}$ (80: $40: 40 \mathrm{~N}: \mathrm{P}: \mathrm{K}$ $\mathrm{kg} / \mathrm{ha} 100 \% \mathrm{RDF}$ ) were $5.45,11.05$ and 11.4 respectively.

\section{Leaf Area Index (LAI)}

Both variety and nutrient management practices significantly influenced the LAI at all growth stages. The leaf area index increased both in variety and nutrient management practices up to 40 DAT and declined after (Table 3). Rice variety Pratiskhya recorded maximum values of LAI than the rice variety Naveen. The maximum LAI of 4.27 was recorded in variety Pratiskhya at 40 DAT and that of Naveen was 3.14. Minimum LAI value was found with Variety Naveen at 20 DAT,

Application of 80:40:40 N: P: K kg/ha $+25 \mathrm{~kg}$ $\mathrm{ZnSO}_{4} / \mathrm{ha}+10 \mathrm{~kg}$ Borax/ha recorded the highest leaf area index followed by that of $\mathrm{F}_{3}$ $\left(\mathrm{F}_{1}+25 \mathrm{~kg} \mathrm{ZnSO} / \mathrm{ha}\right)$ and $\mathrm{F}_{2}(100: 50: 50 \mathrm{~N}: \mathrm{P}$ : $\mathrm{K} \mathrm{kg} / \mathrm{ha125 \%} \mathrm{RDF}$ ) at all stages of crop growth. But latter two were at par with each other. Application of $F_{1}$ (80: 40: $40 \mathrm{~N}: \mathrm{P}: \mathrm{K}$ $\mathrm{kg} / \mathrm{ha}$ ) had minimum LAI of 1.44at 20 DAT than $F_{4}\left(F_{1}+10 \mathrm{~kg}\right.$ Borax/ha $)$ among the nutrient management practices. The response to NPK alone and NPK with either S or Zn or $\mathrm{B}$ or their combination was clearly evident. This varied response might be due to differential uptake of nutrients and their utilisation and impact on growth characters.

\section{Yield and yield attributes}

\section{Panicle weight (g)}

Data on weight of panicle on rice varieties and nutrient management practices (Table 1) revealed differences between the varieties were non-significant and significant differences among the nutrient management 
practices. Pratiskhya variety recorded the maximum panicle weight $2.68 \mathrm{~g}$ which was significantly superior to variety Naveen that had a panicle weight of $2.63 \mathrm{~g}$ and both were at par

The treatment $\mathrm{F}_{1}+25 \mathrm{~kg} \mathrm{ZnSO} / \mathrm{ha} .+10 \mathrm{~kg}$ Borax/ ha recorded the maximum mean panicle weight $(3.03 \mathrm{~g})$ followed by the treatment $\mathrm{F}_{3}\left(\mathrm{~F}_{1}+25 \mathrm{~kg} \mathrm{ZnSO}_{4} / \mathrm{ha}\right)$ which had a panicle weight of $2.86 \mathrm{~g}$. Application of $125 \%$ RDF was found superior to only NPK+ Boron application. Application of NPK and $\mathrm{Zn}$ and $\mathrm{NPK}+\mathrm{Zn}+\mathrm{B}$ did not differ much among themselves.

\section{Panicle per $\mathbf{m}^{2}$}

The varieties and nutrients significantly influenced the number of panicle $/ \mathrm{m}^{2}$ during the year of study (Table 1). Pratiskhya recorded the maximum panicle per $\mathrm{m}^{2}(293.6)$ which was significantly superior than variety Naveen which had 264.6 panicle per $\mathrm{m}^{2}$.

Panicle per $\mathrm{m}^{2}$ differed significantly with regard to nutrient management practices. Application of 80: 40: $40 \mathrm{~N}: \mathrm{P}: \mathrm{K} \mathrm{kg} / \mathrm{ha}+25 \mathrm{~kg}$ $\mathrm{ZnSO}_{4} / \mathrm{ha}$. + $10 \mathrm{~kg}$ Borax/ ha produced the maximum number panicle per $\mathrm{m}^{2}$ 315.0)followed by the treatment $\mathrm{F}_{3}=$ $\mathrm{F}_{1}+25 \mathrm{~kg} \mathrm{ZnSO}_{4} / \mathrm{ha} \mathrm{(299.0)}$ and $\mathrm{F}_{2}$ 100: $50: 50$ $\mathrm{N}: \mathrm{P}: \mathrm{K} \mathrm{kg}$ / ha. $125 \%$ RDF (277.5).

Recommended dose of nutrient application (80: 40: $40 \mathrm{~N}$ : P: K kg/ha) could record only 246.0 numbers panicle per $\mathrm{m}^{2}$. $\mathrm{Zn}$ application along with NPK was found superior to NPK and $\mathrm{B}$ application.

\section{Thousand grain weight}

No significant difference in test weight among the varieties were evident (Table 1). Pratiskhya and Naveen variety recorded test weight values 23.61 and $22.16 \mathrm{~g}$ which were at par with each other. However, there were significant differences among the nutrient management practices.

Among the nutrient management practices, the treatment $\mathrm{F}_{1}+25 \mathrm{~kg} \mathrm{ZnSO} / \mathrm{ha}$. + $10 \mathrm{~kg}$ Borax/ ha produced bold grains with significantly higher test weight of $24.5 \mathrm{~g}$ followed by that of $\mathrm{F}_{3}\left(\mathrm{~F}_{1}+25 \mathrm{~kg} \mathrm{ZnSO} / \mathrm{ha}\right) \mathrm{andF}_{2}$ (100: 50: 50 $\mathrm{N}: \mathrm{P}: \mathrm{K} \mathrm{kg} /$ ha. $125 \% \mathrm{RDF})$ which had thousand grain weight of 23.99 and $23.71 \mathrm{~g}$, respectively. The treatment $\mathrm{F}_{1}(80: 40: 40 \mathrm{~N}$ : $\mathrm{P}$ : $\mathrm{K} \mathrm{kg} / \mathrm{ha}$ recorded the minimum grain weight of $20.70 \mathrm{~g}$. Application of additional dose of NPK did not prove superior to RDF and $\mathrm{Zn}$ or $\mathrm{RDF}$ and $\mathrm{B}$ which clearly indicated clear role of $\mathrm{Zn}$ and $\mathrm{B}$ in rice nutrition.

\section{Number of fertile grains per panicle}

Varieties and nutrient management practices affected significantly the number of fertile grains per panicle (Table 1). Pratiskhya variety recorded the maximum numbers of fertile grains per panicle (136.24) which was significantly superior to Naveen that had 127.96 fertile grains perpanicle. This can be ascribed to fewer number of panicles per unit area and shorter panicles exhibited by Naveen variety. Among the nutrient management practices, the treatment $\mathrm{F}_{1}+25 \mathrm{~kg}$ $\mathrm{ZnSO}_{4} / \mathrm{ha}$. $10 \mathrm{~kg}$ Borax / ha produced maximum number fertile grains per panicle (161.62) followed by that of $F_{3} F_{1}+25 \mathrm{~kg}$ $\mathrm{ZnSO}_{4} /$ ha (148.56) and $\mathrm{F}_{2} 100: 50: 50 \mathrm{~N}: \mathrm{P}: \mathrm{K}$ $\mathrm{kg} / \mathrm{ha}(136.58)$. The treatment $\mathrm{F}_{1}$ (80: 40: 40 $\mathrm{N}: \mathrm{P}: \mathrm{K} \mathrm{kg} / \mathrm{ha} 100 \% \mathrm{RDF}$ ) recorded the minimum fertile grains per panicle (102.46). Many workers reported that combined application of NPK with $\mathrm{Zn}$ and B increases nutrient uptake required for vegetative growth, contribute carbohydrates for photosynthetic activity resulting in better partitioning of assimilates to sink there by increasing filled grains per panicle (Katyal and Agarwal, 1982; Dixit and Khanda, 1994). 
Table.1 Effect of rice varieties and nutrient management practices on yield attributing characters

\begin{tabular}{|c|c|c|c|c|c|c|c|}
\hline Varieties & $\begin{array}{c}\text { Panicle } \\
\text { length }(\mathrm{cm})\end{array}$ & $\begin{array}{c}\text { Panicle } \\
\text { weight (g) }\end{array}$ & $\begin{array}{c}\text { Panicle per } \\
\mathbf{m}^{2}\end{array}$ & $\begin{array}{l}1000 \text { grain } \\
\text { weight (g) }\end{array}$ & $\begin{array}{c}\text { Fertile } \\
\text { grains per } \\
\text { panicle }\end{array}$ & $\begin{array}{c}\text { Sterile } \\
\text { grains per } \\
\text { panicle }\end{array}$ & $\begin{array}{c}\text { Grain } \\
\text { yield(t/ha) }\end{array}$ \\
\hline$V_{1}$ Naveen & 23.05 & 2.63 & 264.6 & 22.16 & 127.96 & 34.81 & 4.23 \\
\hline$V_{2}$ Pratiskhya & 24.77 & 2.68 & 293.6 & 23.61 & 136.24 & 28.53 & 5.10 \\
\hline $\mathrm{SE}(\mathrm{m}) \pm$ & 0.32 & 0.12 & 3.63 & 0.26 & 2.23 & 1.17 & 0.23 \\
\hline $\mathrm{CD}(\mathrm{P}=\mathbf{0 . 0 5})$ & 0.94 & NS & 10.95 & 0.77 & 6.67 & 3.15 & 0.68 \\
\hline \multicolumn{8}{|c|}{ Nutrient management practices } \\
\hline$F_{1}=80: 40: 40$ N:P:K kg/ha(100\% RDF $)$ & 20.03 & 2.39 & 246.0 & 20.70 & 102.46 & 31.82 & 3.97 \\
\hline $\begin{array}{c}F_{2}=100: 50: 50 \text { N:P:K kg/ha(125\% } \\
\text { RDF })\end{array}$ & 25.68 & 2.71 & 277.5 & 23.71 & 136.58 & 38.83 & 4.95 \\
\hline $\mathrm{F}_{3}=\mathrm{F}_{1}+25 \mathrm{kgZnSO}_{4} / \mathrm{ha}$ & 26.41 & 2.86 & 299.0 & 23.99 & 148.56 & 25.06 & 4.99 \\
\hline $\mathrm{F}_{4}=\mathrm{F}_{1}+10 \mathrm{kgBorax} / \mathrm{ha}$ & 22.78 & 2.30 & 258.0 & 21.53 & 130.31 & 25.85 & 4.12 \\
\hline $\mathrm{F}_{5}=\mathrm{F}_{1}+25 \mathrm{kgZnSO}_{4} / \mathrm{ha}+10 \mathrm{kgBorax} / \mathrm{ha}$ & 27.64 & 3.03 & 315.0 & 24.50 & 161.62 & 23.52 & 5.67 \\
\hline $\operatorname{SEm}( \pm)$ & 0.43 & 0.18 & 4.90 & 0.28 & 3.81 & 1.87 & 0.28 \\
\hline $\mathrm{CD}(\mathrm{P}=0.05)$ & 1.28 & 0.56 & 14.66 & 0.82 & 11.38 & 5.85 & 0.82 \\
\hline
\end{tabular}

Table.2 Interaction effect of variety with nutrient management practices(t/ha)

\begin{tabular}{|c|c|c|c|c|c|}
\hline \multirow{2}{*}{ Variety } & \multicolumn{5}{|c|}{$\begin{array}{c}\text { Nutrient management practices } \\
\text { Yield (t/ha) }\end{array}$} \\
\cline { 2 - 5 } & $\mathbf{F}_{\mathbf{1}}$ & $\mathbf{F}_{\mathbf{2}}$ & $\mathbf{F}_{\mathbf{3}}$ & $\mathbf{F}_{\mathbf{4}}$ & $\mathbf{F}_{\mathbf{5}}$ \\
\hline $\mathbf{V}_{\mathbf{1}}$ & 3.50 & 4.45 & 4.46 & 3.64 & 5.12 \\
\hline $\mathbf{V}_{\mathbf{2}}$ & 4.27 & 5.29 & 5.39 & 4.65 & 6.07 \\
\hline & Interaction SE(m) $+\mathbf{0} \mathbf{0 . 3 2}$ & $\mathbf{C D}$ at 5\%: $\mathbf{0 . 9 4}$ & \\
\hline
\end{tabular}


Table.3 Number of tillers per hill, plant height and LAI ( leaf area index) at successive Stage of Growth as influenced by rice varieties and nutrient management practices

\begin{tabular}{|c|c|c|c|c|c|c|c|c|c|c|}
\hline \multirow[b]{2}{*}{ Varieties } & \multicolumn{3}{|c|}{ Tillers per hill } & \multicolumn{3}{|c|}{ Plant height(cm) } & \multirow[b]{2}{*}{$\begin{array}{c}\text { At } \\
\text { harvest }\end{array}$} & \multicolumn{3}{|c|}{ LAI } \\
\hline & 20DAT & 40DAT & 60DAT & 20DAT & 40DAT & 60DAT & & 20DAT & 40DAT & 60DAT \\
\hline$V_{1}$ Naveen & 6.44 & 12.76 & 13.62 & 48.0 & 71.2 & 89.0 & 91.0 & 1.79 & 3.14 & 2.29 \\
\hline$V_{2}$ Pratiskhya & 8.06 & 13.52 & 14.22 & 51.2 & 73.8 & 93.6 & 95.8 & 2.17 & 4.27 & 3.38 \\
\hline $\mathrm{SE}(\mathrm{m}) \pm$ & 0.58 & 0.65 & 0.71 & 0.72 & 1.35 & 0.98 & 0.93 & 0.26 & 0.31 & 0.30 \\
\hline $\mathrm{CD}(\mathrm{P}=\mathbf{0 . 0 5})$ & 1.72 & NS & NS & 2.13 & NS & 2.88 & 2.77 & 0.77 & 0.91 & 0.88 \\
\hline \multicolumn{11}{|c|}{ Nutrient management practices } \\
\hline $\begin{array}{c}F_{1}=80: 40: 40 \text { N:P:K } \\
\text { kg/ha(100\% RDF) }\end{array}$ & 5.45 & 11.05 & 11.4 & 37.0 & 59.5 & 79.0 & 81.5 & 1.44 & 2.79 & 1.68 \\
\hline $\begin{array}{c}F_{2}=100: 50: 50 \text { N:P:K kg/ha(125\% } \\
\text { RDF })\end{array}$ & 7.85 & 14.1 & 14.65 & 55.0 & 77.5 & 94.5 & 97.0 & 2.09 & 3.54 & 3.15 \\
\hline $\mathrm{F}_{3}=\mathrm{F}_{1}+25 \mathrm{kgZnSO}_{4} / \mathrm{ha}$ & 8.35 & 13.5 & 15.25 & 56.5 & 80.5 & 99.5 & 101.5 & 2.33 & 4.18 & 3.39 \\
\hline$F_{4}=F_{1}+10 \mathrm{kgBorax} / \mathrm{ha}$ & 5.65 & 11.55 & 12.05 & 40.0 & 61.0 & 78.0 & 84.5 & 1.56 & 3.55 & 1.92 \\
\hline $\mathrm{F}_{5}=\mathrm{F}_{1}+25 \mathrm{kgZnSO}_{4} / \mathrm{ha}+10 \mathrm{kgBorax} / \mathrm{ha}$ & 8.95 & 15.5 & 16.2 & 59.5 & 84.0 & 103.0 & 105.0 & 2.48 & 4.45 & 4.03 \\
\hline $\mathrm{SE}(\mathrm{m}) \pm$ & 0.45 & 0.82 & 0.53 & 0.86 & 1.24 & 1.10 & 1.23 & 0.28 & 0.37 & 0.45 \\
\hline $\mathrm{CD}(\mathrm{P}=\mathbf{0 . 0 5})$ & 1.34 & 1.82 & 1.58 & 2.52 & 3.68 & 3.21 & 3.68 & 0.83 & 1.10 & 1.32 \\
\hline
\end{tabular}




\section{Number of sterile grains per panicle}

Rice varieties and nutrient management practices affected significantly the number of sterile grains per panicle (Table 1). Pratiskhya variety recorded the minimum sterile grains per panicle 28.53 which was significantly superior to variety Naveen 34.81 sterile grains per panicle. Fewer number of sterile grains with the variety Pratiskhya can be attributed to the genetic quality of the variety over the prevailing Variety Naveen.

Among the nutrient management practices, 80: 40 : $40 \mathrm{~N}: \mathrm{P}: \mathrm{K} \mathrm{kg} /$ ha $+25 \mathrm{~kg} \mathrm{ZnSO} 4 /$ ha. + 10 $\mathrm{kg}$ Borax / ha resulted in minimum number of sterile grains per panicle 23.52. The treatment $\mathrm{NPK}+\mathrm{Zn}$ and NPK $+\mathrm{B}$ had more or less same number of sterile grains and was at par. Application of $125 \%$ RDF had more sterile grains which indicated that the nutrient application above the recommended dose was not economical.

\section{Grain yield}

Varieties and nutrient management practices influenced the grain yield significantly (Table 1). Pratiskhya proved to be the highest yielder and produced (5.10 tonne grains/ ha.) which was significantly superior to variety Naveen 4.23 tonne grains/ha. The yield increase was to the extent of $20.6 \%$ over Naveen. Higher grain yield could be due to cumulative favourable effects of all yield contributing characters viz. grains/panicle, productive tillers/panicle, higher thousand grain weight and fewer number of sterile grains /panicles.

Among the nutrient management practices, the treatment $\mathrm{F}_{1}+25 \mathrm{~kg} \mathrm{ZnSO} / \mathrm{ha}$. + $10 \mathrm{~kg}$ Borax / ha produced the maximum grain yield $(5.67 \mathrm{t} /$ ha) followed by the treatment $F_{3}: F_{1}+25 \mathrm{~kg}$ $\mathrm{ZnSO}_{4} / \mathrm{ha}$ ) that recorded $4.99 \mathrm{t} / \mathrm{ha}$ and the yield difference was $13.6 \%$. Application of RDF 80: 40: $40 \mathrm{~N}$ : P: $\mathrm{K} \mathrm{kg} / \mathrm{ha}$ ) recorded the minimum grain yield of $3.97 \mathrm{t} / \mathrm{ha}$. The treatments $125 \% \mathrm{NPK}, 100 \% \mathrm{NPK}+\mathrm{Zn}$ and $100 \%$ NPK + B did not differ among themselves and were accordingly at par. Higher grain yield with combination of NPK+ $\mathrm{Zn}+\mathrm{B}$ over $\mathrm{NPK}+\mathrm{Zn}$ or $\mathrm{NPK}+\mathrm{B}$ may be attributed to better manifestation of all yield contributing characters associated with the treatment. This resulted in higher uptake of NPK, Zn and B over other treatment combinations. Interaction effect was also found significant Table 2. Variety Naveen with application of $\mathrm{NPK}+\mathrm{ZnSO}_{4}+$ Borax recorded an yield of $5.12 \mathrm{t} / \mathrm{ha}$ as against production of $6.07 \mathrm{t} / \mathrm{ha}$ in Pratiskhya under same management practices and the difference was statistically significant. Variety Pratiskhya with nutrient application of NPK+ $\mathrm{ZnSO}_{4}$ only recorded a yield of $5.39 \mathrm{t} / \mathrm{ha}$ which was more than that of $\mathrm{NPK}+\mathrm{ZnSO}_{4}+$ Borax in Naveen.

Rice variety Pratiskhya with nutrient combination of NPK @ 80:40:40 kg/ha+ZnSO ${ }_{4} @ 25$ kg/ha+Borax@10 kg/ha recorded higher uptake of different nutrients $(\mathrm{S}, \mathrm{Zn}, \mathrm{B}, \mathrm{N}, \mathrm{P}$ and $\mathrm{K})$. For efficient rice production in acid sandy loam soil under Bhubaneswar agro-climatic condition, application of $\mathrm{S}, \mathrm{Zn}$ and $\mathrm{B}$ is essential and the added nutrients had beneficial effect on the following rice crop and the nutrient status of the soil.

\section{References}

Mohapatra AK. 2004. Studies on direct and residual effect of secondary and micronutrients in Rice (Hybrid) - rice cropping sequence. Ph.D. thesis. Department of Agronomy, OUAT, Bhubaneswar.

Katyal JC and Agarwal SC. 1982. Micronutrient research in India. Fertilizer News, 27:66-86.

Mahajan, G., Sekhon, N.K., Singh, N., Kaur, 
Rand Sidhu, A.S. (2010). Yield and nitrogen - use efficiency of aromatic rice cultivars in response to nitrogen fertilizer, Journal of New Seeds.11(4): 356-368.

Khanda CM, Dixit L and Panda SC. 1997. Effect of zinc and graded levels of nitrogen on growth, yield and nutrient uptake of rice, Oryza 34: 43-46.

Dixit L and Khanda CM. 1994. Effect of Zinc and nitrogen fertilization on yield and yield attributes of summer rice. Orissa Journal of Agricultural Research, 7: 115.

\section{How to cite this article:}

Sudeshnamayee Sahoo, Koushik Sar, A. K. Mohapatra and Gulati, J. M. L. 2019. Effect of Nutrient Management in Growth, Development and Productivity of Late Transplanted Rice (Oryza sativa L.). Int.J.Curr.Microbiol.App.Sci. 8(12): 685-692.

doi: https://doi.org/10.20546/ijcmas.2019.812.090 